Journal of Education and Vocational Research

Vol. 4, No. 2, pp. 36-46, Feb 2013 (ISSN 2221-2590)

\title{
The influence of Company Characteristics Factors to Activity Based Costing System Implementation
}

\author{
Abedalqader Rbaba'h \\ Jarash University, Jordan \\ abedalqader.rababah@gmail.com
}

\begin{abstract}
This study tried to determine the implementation of activity based costing system rate and to examine the relationship between company characteristics such as industry type, numbers of employees, numbers of products, and level of overhead and $\mathrm{ABC}$ implementation. The findings revealed that $\mathrm{ABC}$ implementation in the context of Jordanian Manufacturing Companies is approximately $19.5 \%$ measured according to the number of implementers companies within Jordanian Manufacturing Companies. In order to test hypotheses Logistic regression and chi-square used in the current study. The findings in this study reveals that company sectors, size - number of employees, diversity -number of product, and level of overhead cost don't have significant influence on the implementation of $A B C$ among manufacturing shareholding firms in Jordan. Therefore hypotheses H1a, H1b, H1c, H2, H3, and H4 are rejected.
\end{abstract}

Keywords: Activity-based costing (ABC), Implementers, Manufacturing companies, Jordan

\section{Introduction}

Since the past two decades, Jordanian companies have been facing strong competition due to shortened product life cycles and new kinds of customers (Abu Mogli, 2008). In this environment, the number of products produced had increased with more complexity and diversity in the production process. While the use of technology in the production process had reduced direct labors cost, it increased overhead costs (AlKhadash \& Feridun, 2006; Hutaibat, 2005). Khaleel (2003) examined the limitations of traditional full absorption costing systems by implementing $\mathrm{ABC}$ as an alternative system in one of the leading companies in the Jordanian manufacturing companies. The study showed a significant variation between product costs as a result of the implemented $A B C$. Some products were produced below cost while others above cost. The researcher recommended that Jordanian companies implement $A B C$ to eliminate the products which causing loss. Many studies have highlighted the disadvantages of the traditional accounting systems particularly its adherence to the postulation that both products and services are the primary reason for creating costs (Cooper, 1988; Green \& Flentov, 1991). According to some researchers like Datar \& Gupta (1994), costs are often allocated on the basis of single-volume measures like direct-labor costs or machine hours. They added that because of this, the possibility of distortions arise in determining or calculating various types of costs. In addition, Gunasekaran (1999) stated that traditional cost systems fail to provide accurate measurement of activity performance and any information regarding value added activities. Prior studies including Innes, Mitchell \& Sinclair (2000), Popesko (2010), and Turney (1996) defined ABC as method of measuring cost and performance of activities and cost objects. The cost to activities is gauged through the use of resources and cost is assigned to cost objects based on their activities use. This is different from the traditional cost accounting where cost is gauged through resource consumption (Vongchavalitkul, 2010).

Regardless of its several benefits, many studies on a global scale report low adoption percentage of ABC (Askarany \& Smith, 2008; Innes et al., 2000; Innes \& Mitchell, 1995; Kaplan \& Anderson, 2004; Stratton, Desroches, Lawson, \& Hatch, 2009). Other studies (e.g. Arnaboldi \& Lapsley, 2003; Byrne, Stower \& Torry, 2009; Chung, Schoch \& Teoh, 1997; Faudziah \& Rababah, 2011, 2012; Rasiah, 2011; Velmurugan \& Nahar, 2010). They also evidenced that those companies who adopted $A B C$ are still in the infancy phase of implementation as most companies who tried implementing it ultimately succeeded in employing its narrow application in trivial services and in unused systems. There is notable evidence to indicate that most of the companies faced $\mathrm{ABC}$ implementation challenges and in worst cases, did not overcome them, which eventually culminated in $\mathrm{ABC}$ system abandonment. However, despite the challenges, the traditional costing 
system is still increasingly implemented in several companies (Al-Omiri \& Drury, 2007b; Askarany \& Smith, 2008; Innes et al., 2000; Marie \& Rao, 2010) raising a reasonable question as to why management accounting innovations like $\mathrm{ABC}$ indicate slow adoption in the dynamic changes in the organizational and technological environment in the past twenty years. Various interpretative points of view have been brought forward by researchers to understand and highlight the factors impacting ABC adoption and implementation (Maelah \& Ibrahim, 2006; Malami, 1999; Rahmouni \& Charaf, 2010; Shield, 1995) but most of them have reached ambiguous, different and divergent findings. Velmurugan and Nahar (2010) highlighted the absence of common factors that contribute to the $\mathrm{ABC}$ implementation of those companies that have used $\mathrm{ABC}$ for a significant period of time.

Owing to the inconclusive findings, more studies are needed to investigate the case in an in-depth manner in general and in Jordan, in particular. Fei \& Isa (2010b) revealed that most of the literature's empirical research has been conducted in the West and only a few were done in the developing countries concerning $A B C$ adoption and implementation, particularly countries characterized by rapid economic growth. In the context of Jordan, Hutaibat (2005) noted that Jordan's economy shows increasing development especially following its membership to the World Trade Organization (WTO) and its assignation to free trade agreement with many countries. Hence, changes are expected to appear in management accounting practices and innovations in Jordanian companies in their quest to obtain competitive advantage. It is crucial for companies to plan, control and make decisions concerning projects that will result in significant outcome in order to survive and this is only possible through the use of cost accounting innovations (Hutaibat, 2005). Moreover, the fact that the number of multinationals setting up business in the region is increasing, it is expected that Jordanian manufacturing companies increase their influence by adopting foreign accounting practices. Despite the divergence in the cost accounting practices globally (Luther \& Longden, 2001, p. 315), it is still possible to adopt and employ some practices form international partners.

\section{Literature Review}

The expansive changes in the environment has urged many companies to undergo changes and redesigning in their business and competitive strategies, specifically in their management system, in the quest to achieve a competitive advantage in the market environment. Companies that are successful are capable of getting superior quality, lower costs and efficiency of operations and of getting rid of products and services causing losses (Cooper, 1988; Innes \& Mitchell, 1991; Kaplan, 1988; Krishnan, 2006). Furthermore, several industrial firms have transformed from labor intensive to machine intensive production processes; a transformation that has led to significant overhead costs which calls for accurate cost allocation to products. Other firms have switched from traditional cost accounting to activity based costing system. According to Innes \& Mitchell (1995), ABC is capable of providing a more accurate overhead cost allocation and along the same line, researchers (Kruemwield, 1998; McGowan \& Klammer, 1997; and Shield, 1995) elaborated that ABC was created as a practical solution to issues related with traditional costing system and the conventional costing system's failure to provide superior quality information in the new market environment. More importantly, another reason for $\mathrm{ABC}$ adoption is the increasingly competitive marketplace where most competitors have employed it as it has become a requirement of enhancing product quality for customers (Chongruksut, 2002; Maelah \& Ibrahim, 2006). In the context of Malaysia, Majid and Sulaiman (2008) stressed that parent company or headquarters mandate is also one of the reasons behind $\mathrm{ABC}$ adoption and implementation.

Cooper (1991) stated that increasing costs and products diversity is also a primary reason for the adoption and implementation of $\mathrm{ABC}$ while Cohen et al. (2005) elaborated by adding that support for other management practices including TQM and JIT is significant in the adoption of the activity based costing system. Similarly, Campbell, Brewer \& Mills (1997) revealed that ABC adoption and implementation is attributed to its assistance in providing accurate information to help management decision-making. In a related study, Chongruksut (2002) investigated ABC systems adoption in various sectors in Thailand through the survey method and revealed that the Thailand financial crisis of 1995 and the following economic recession had played a major role in the adoption of activity based costing. Additionally, a model of the factors that motivate ABC considerations was developed and tested by Brierly (2009). The study involved 854 companies in the manufacturing industry in Great Britain and the model was tested through the use of ordinal regression analysis with the $\mathrm{ABC}$ level of consideration as the dependent variable and the competition 
level, product customization level, percentage share of the manufacturing overhead costs to total manufacturing costs and operating unit size as the independent variables. The findings revealed that operating unit size significantly impacts the $A B C$ consideration level. Other constructs had insignificant impacts indicating that the competition level, product customization, manufacturing overhead percentage all failed to impact the decision for ABC consideration. This finding is consistent to Brown et al.'s (2004) findings that revealed technological factors including product customization and cost structure are not associated to the $\mathrm{ABC}$ consideration of operating units. They further found insignificant impact of environmental factors including competition. Meanwhile, Van Nuyen and Brooke (1997) showed a positive relation between motivator factors including change in cost structure, ABC adoption and competition. AlOmiri \& Drury (2007a) also revealed a positive link between competition and ABC adoption. Similarly, Booth and Giacobbe (1998) and Cooper (1988) revealed a positive link between overhead level and adoption of ABC.

Earlier studies like Shield (1995) attempted to establish a relation between ABC adoption and environmental factors including globalization, deregulation, and customer demand. He revealed that the dynamic changes of these factors lead to shifts in practices of management accounting. In a related study, Innes \& Mitchell (1990) noted that the changes in the external environment including globalization and lower operating costs of competitors motivate shift in management accounting. On the other hand, Brierly (2009) recommended that more research should conduct a longitudinal study to examine the when and how of the consideration completion. In Iran, Ahmadzadeh et al. (2011) conducted a questionnaire survey in Iranian companies which are listed in Tehran Stock Exchange using the logistic regression model from 57 companies (33.5\%) as respondents in the sample. This research seeks to examine if the organizational factors such as organization size, industry type, cost structure, the importance of cost information, and products and services diversity have a role in motivating the implementation of Activity-Based costing (ABC). The results of this study found a positive association between cost structure, the importance of cost information and products and services and $\mathrm{ABC}$ implementation. It also found a negative association between the type of industry, organization size and product and services diversity and ABC implementation. Ahmadzadeh et al. (2011) recommended that future research should examine some variables to know their influence on adoption and implementation of Activity-Based costing (ABC). These variables are: competition, level of fixed costs, organizational life cycle stage, economical crisis, top management support, quality of information technology, resistance to change by providers, users of accounting information and lack of relevant employees' skills.

Hypotheses Development: In the following sections the main hypotheses are described. It's focusing on the hypotheses relating to the important objective which related to company characteristics factors influencing the implementation /non-implementation of $\mathrm{ABC}$ systems. The research hypotheses address company characteristics factors which includes (i) Industry type (ii) company size (Number of Employees) (iv) Products diversity (Number of Product) (v) level of overhead costs. However, this study intends to find out whether the independent variables have a significant impact on the implementation of $\mathrm{ABC}$ systems, Therefore In the following sub-sections the literature is drawn off to develop hypotheses relating to each of the above factors. Table 1 shows a summary of the independent variables used in the present study.

Table 1: Summary of Independent Variable

\begin{tabular}{ll}
\hline Variable & Definition \\
\hline Company Sector & Type of sector \\
company size & Number of employees \\
Products diversity & Number of product \\
Level of Overhead & Degree of potential cost distortion \\
\hline
\end{tabular}


Company Sector: In another related study, Shields (1997) contended that the cost accounting information design, effectiveness and systems depend on the industries' characteristics. The literature concerning innovation diffusion also indicates that organizations within an industry sector may imitate one another. Hence, the process of imitation may lead to similar adopted accounting systems within a single business sector. In the case of $\mathrm{ABC}$, its inital introduction was in the manufacturing organizations and according to mimicking behavior of organizations, manufacutring organizations may be more inclined to adopt sophisticated costing systems (Al-Omiri \& Drury, 2007).

Hypothesis 1: There is a positive relationship between type of sector and $\mathrm{ABC}$ implementation.

Based on the Department of Statistics Reports and Ministry of Industry and Trade in Jordan, they classified the eleven type of sectors which have the same characteristics into three groups, first one was called the engineering sector, and this group includes two sectors, namely: electrical, and engineering and construction industries. The second one was called the processing sector, and this group includes four sectors, namely: chemical industries, medical industries, glass and Ceramic industries, and Mining and Extraction industries. The last one is called consumers product sector, and this group includes five sectors, namely: food and beverages, tobacco and cigarettes, textiles, leathers and clothing, paper and carton industries, and printing and packaging, the benefit of this classification it will make the data analysis valid. Therefore, the following hypotheses is formulated as branches to the main hypothesis:

Hypothesis 1a: There is a positive relationship between type of sector - Engineering sector and $\mathrm{ABC}$ implementation.

Hypothesis 1b: There is a positive relationship between type of sector - Processing sector and ABC implementation.

Hypothesis 1c: There is a positive relationship between type of sector - Consumers sector and $\mathrm{ABC}$ implementation.

Company Size: Krumwiede (1998) pointed out that the reasons for the significant size effect in prior ABC implementation research are unclear. A possible reason for this is that larger firms have relatively greater access to resources to experiment with the introduction of innovative systems such as ABC. Several surveys have also indicated that an important factor limiting the implementation of innovation of $\mathrm{ABC}$ is the prohibitive cost (Inns \& Mitchell, 1995; Shields, 1995). As larger firms have more resources to develop innovative systems, it is also more likely that they will be able to adopt and implement more sophisticated costing systems or any innovation. Larger firms also have a larger network of communication channels and the necessary infrastructure for adopting $\mathrm{ABC}$ and they may have a larger and more diversified range of activities leading to greater product, service and customer diversity. This situation may create the need for more sophisticated costing systems such as $\mathrm{ABC}$ to measure resource consumption by different cost objects (Bjørnenak, 1997; Brown et al., 2004). In empirical research, Brown et al. (2004) found that the number of employees was positively related to whether operating units were considering or had considered ABC. However, there is a range of factors that could be used to describe company size, such as number of employees, annual sales, total revenue, net worth, total assets and capital. Askarany and Smith (2008) recommended that companies are most commonly classified by size according to the number of employees and size of capital. Therefore, the number of employees is used to measure the company size in the present study. Therefore, the following hypothesis is formulated:

Hypothesis 2: There is a positive relationship between the size of the organization - Number of Employees and $\mathrm{ABC}$ implementation.

Products diversity: Product diversity leads to a higher potential for cost distortion and applies when products consume activity resources in different proportions. Greater product diversity requires more sophisticated costing systems to capture the variation in resource consumption by different products. Cooper (1988b) point out that product diversity includes support, process and volume diversity. Support diversity refers to varying support given to each product by various support departments whereas process diversity refers to differences in consumption among all identifiable activities relating to product design, manufacture, and distribution. Volume diversity occurs when products are manufactured in different batch sizes thus affecting how batch level costs should be assigned to products. The more complex the production process the more complex the costing system that is required to model it (Malmi, 1999). Product diversity determines production process complexity resulting in more activities being required to manufacture them. Thus, to 
measure the resource consumption of different products in a complex setting, sophisticated costing systems are required. Based on the above discussion the following hypothesis is formulated:

Hypothesis 3: There is a positive relationship between higher levels of products diversity- Number of products and $\mathrm{ABC}$ implementation.

Level of Overhead: When higher levels of overhead costs are incurred to produce products, it is argued that there is a greater need to use product costing systems to capture those costs in product costs (Bjørnenak, 1997). When overhead costs (excluding facility-level costs) make up a high proportion of total product costs, Kaplan and Cooper (1998) consider that ABC should be used. In research into the consideration for ABC, Brown et al. (2004) did not observe a significant effect for overhead costs to value added costs on operating units that were considering or had considered ABC verses those that had not considered it. In contrast, Booth and Giacobbe (1998) found that operating units with a higher rate of overhead costs to value added costs in operating units had shown an interest in ABC. Operating units with a higher rate of manufacturing overhead costs to total manufacturing overhead costs would be expected to be more likely to have implemented or to be implementing ABC. Based on the above discussion the following hypothesis is formulated:

Hypothesis 4: There is a positive relationship between the Level of Overhead in an organization's cost structure and the implementation of ABC.

\section{Methodology}

Questionnaire survey was used in the current study, 92 surveys were distributed within the Jordanian manufacturing companies. The aim of the questionnaire is to know the implementation rate and to know the influence of Company Characteristics Factors to Activity Based Costing System Implementation in the Jordanian manufacturing companies. This process took place from 1th October to $2^{\text {th }}$ December 2011. Ninetytwo questionnaires were distributed and eighty-two questionnaires returned, thereby giving a response rate of $89 \%$. A phone call and personal interviews were made afterwards to improve the response rate.

\section{Data analysis}

Implementation rate: Based on the results of the questionnaire survey, companies are classified as follows:

Table 2: Number of Companies in each Category of ABC Implementation

\begin{tabular}{ll}
\hline Name of the Stage & Number of the Companies \\
\hline Implementers & 16 \\
Non-implementers & 66 \\
\hline
\end{tabular}

Based on the above results the $\mathrm{ABC}$ implementation in the Jordanian Manufacturing Companies is approximately $19.5 \%$ measured according to the number of implementers companies within Jordanian Manufacturing Companies.

Factors analysis: In order to test hypotheses Logistic regression will be used in the current study. Logistic regression can only be used where there are two dichotomous categories (e. g. ABC Implementation and non$\mathrm{ABC}$ implementation). Under logistic regression, the normality is not necessarily the same for both dependent and independent variables. Hair et al. (1998) state that logistic regression is one of the most widely used linear probability models. Logistic regression has been used and reported in the published management accounting research journals and has been used in previous ABC research (Ahmadzadah et al., 2011; Gosselin, 1997 \& Krumwiede, 1998). Based on the above discussion, logistic regression was chosen to test the hypotheses relating to the influence of the Company characteristics factors on the implementation/nonimplementation of ABC. As for this study, the model was adapted from as Ahmadzadah et al. (2011). The organizations are divided into two groups, implementers and non-implementers, in the following logistic regression equation:

$\mathrm{Y}=\mathrm{b} 1+\mathrm{b} 2(\mathrm{~V} 1 \mathrm{a})+\mathrm{b} 3(\mathrm{~V} 1 \mathrm{~b})+\mathrm{b} 4(\mathrm{~V} 1 \mathrm{c})+\mathrm{b} 5(\mathrm{~V} 2)+\mathrm{b} 6$ (V3) + b7 (V4) +e

Where: 
$(Y=1)=$ the probability of $\mathrm{ABC}$ implementation

$\mathrm{V} 1 \mathrm{a}=$ company sector- Engineering

$\mathrm{V} 1 \mathrm{~b}=$ company sector - Processing

$\mathrm{V} 1 \mathrm{c}=$ company sector - Consumers

$\mathrm{V} 2$ = size -number of employees

$\mathrm{V} 3$ = diversity - number of product

$\mathrm{V} 4=$ level of overhead cost

$\mathrm{E}=$ residual error term

Logistic regression (logit) analysis was done on the hypotheses. It is formulated to predict and explain twocategorical variable (Hair et al. 1998). logit estimates models in which the dependent variable can take only two values, 1 and 0 . The overall measure of how well the model fits is given by the likelihood value (-2LL or -2 log likelihood). Hosmer and Lemeshow (1989) develop a classification test where sample is divided into approximately ten equal classes. The number of actual and predicted event is compared in each class with the chi-square statistic. In this study, the two values in which variable take are 1 and 0 where 1 represents the organizations that implement $\mathrm{ABC}$ and 0 represent the organizations that non-implementers. The sample size of the organizations is 16 implementers and 66 non-implementers. Table 3 below, the model were to predict the Y-value as 0 or 1 , the model will be correct 80.5 percent times. This is a high percentage compared to the naïve model of 50 percent.

Table 3: Classification Table (a,b)

\begin{tabular}{|c|c|c|c|c|c|}
\hline & Observe & & Pre & & \\
\hline & & & IMI & & Percentage Correct \\
\hline & & & .00 & 1.00 & \\
\hline Step 1 & IMPLEM & .00 & 66 & 0 & 100.0 \\
\hline & & 1.00 & 16 & 0 & .0 \\
\hline & Overall P & & & & 80.5 \\
\hline
\end{tabular}

a Constant is included in the model, $\mathrm{b}$ The cut value is .500

To determine which variable has significant impact on $\mathrm{ABC}$ implementation Table 4 is referred. The variables will be statistically significant at $\mathrm{p}<0.05$ and $\mathrm{p}<0.10$. From table 4 in this study, the all variables: company sectors, size-number of employees, diversity-number of product, and level of overhead cost are not significant, because $\mathrm{P}>.0 .05$.

Table 4: Variables in the Equation

\begin{tabular}{llllllll}
\hline & & B & S.E. & Wald & df & Sig. & Exp(B) \\
\hline Step 1(a) & SIZE & -.001 & .001 & 1.892 & 1 & .169 & .999 \\
& DIVERS & .001 & .005 & .055 & 1 & .814 & 1.001 \\
& COST & 1.910 & 1.726 & 1.224 & 1 & .268 & 6.752 \\
& ENGIN & & & .937 & 2 & .626 & \\
& PROCE & .372 & .717 & .268 & 1 & .605 & 1.450 \\
& CONSU & -.308 & .708 & .189 & 1 & .663 & .735 \\
& Constant & -1.642 & .912 & 3.246 & 1 & .072 & .194 \\
\hline
\end{tabular}

a Variable(s) entered on step 1: SIZE, DIVERS, COST, SECTOR..

The findings in this study reveals that company sectors, size - number of employees, diversity -number of product, and level of overhead cost don't have significant influence on the implementation of ABC among manufacturing shareholding firms in Jordan. Therefore hypotheses H1a, H1b, H1c, H2, H3, and H4 are rejected. These results explained in more details as follows: The data analysis for first hypotheses shows no any relationship between $\mathrm{ABC}$ implementation and company sector, because the significant value for all company sectors (Engineering, Processing, and Consumers) more than 0.05. Shields (1995) stated that the 
implementation and designing of cost accounting systems are conditional on the characteristics of industries. The literatures related to the diffusion of innovation theory such as Abrahamson (1991) and Malmi (1997) said that the companies within an industry sector may imitate other companies, so the imitation process may result in similar accounting system being adopted within specific business sectors. Al-Omiri and Drury (2007) said that $\mathrm{ABC}$ was initially introduced in manufacturing companies. Thus, mimicking behavior suggests that manufacturing companies may be more likely to adopt sophisticated costing systems.

There are a few implementers in each sector; to enhance the data analysis and to make it more valid a chisquare was employed in the current study. Table 5 presents the classification of ABC Implementers and Non$\mathrm{ABC}$ Implementers based on the type of sector.

Table 5: Classification of ABC Implementers and Non-ABC Implementers Based On Type of Sector

\begin{tabular}{|c|c|c|c|c|c|}
\hline & & & Implementer & $\begin{array}{l}\text { Non- } \\
\text { Implementer }\end{array}$ & \\
\hline \multirow[t]{12}{*}{ SECTOR1 } & \multirow[t]{4}{*}{ Engineering } & Count & 6 & 16 & 22 \\
\hline & & $\%$ within SECTOR1 & $27.3 \%$ & $72.7 \%$ & $100.0 \%$ \\
\hline & & $\begin{array}{l}\% \text { within Implementers -Non } \\
\text { Implementers }\end{array}$ & $37.5 \%$ & $24.2 \%$ & $26.8 \%$ \\
\hline & & $\%$ of Total & $7.3 \%$ & $19.5 \%$ & $26.8 \%$ \\
\hline & \multirow[t]{4}{*}{ Processing } & Count & 5 & 27 & 32 \\
\hline & & $\%$ within SECTOR1 & $15.6 \%$ & $84.4 \%$ & $100.0 \%$ \\
\hline & & $\begin{array}{l}\% \text { within Implementers -Non } \\
\text { Implementers }\end{array}$ & $31.3 \%$ & $40.9 \%$ & $39.0 \%$ \\
\hline & & $\%$ of Total & $6.1 \%$ & $32.9 \%$ & $39.0 \%$ \\
\hline & \multirow[t]{4}{*}{ Consumers } & Count & 5 & 23 & 28 \\
\hline & & \% within SECTOR1 & $17.9 \%$ & $82.1 \%$ & $100.0 \%$ \\
\hline & & $\begin{array}{l}\% \text { within Implementers -Non } \\
\text { Implementers }\end{array}$ & $31.3 \%$ & $34.8 \%$ & $34.1 \%$ \\
\hline & & $\%$ of Total & $6.1 \%$ & $28.0 \%$ & $34.1 \%$ \\
\hline \multirow[t]{4}{*}{ Total } & & Count & 16 & 66 & 82 \\
\hline & & \% within SECTOR1 & $19.5 \%$ & $80.5 \%$ & $100.0 \%$ \\
\hline & & $\begin{array}{l}\% \text { within Implementers-Non } \\
\text { Implementers }\end{array}$ & $100.0 \%$ & $100.0 \%$ & $100.0 \%$ \\
\hline & & $\%$ of Total & $19.5 \%$ & $80.5 \%$ & $100.0 \%$ \\
\hline
\end{tabular}

In the current study, to know if there are statistically significant differences between both $A B C$ Implementers and Non-ABC Implementers based on type of sector, a chi-square was employed. As mentioned before the numbers of companies in some sectors is very small. So, the sectors that had similar characteristics were combined in one group based on the Department of Statistics Reports and Ministry of Industry and Trade in Jordan. Eleven types of manufacturing companies were classified into three groups (Engineering, Processing and Consumers). This decision was organized to increase the number of companies in each group to make the chi-square analysis valid. The data analysis found no main difference between ABC Implementers and NonABC Implementers based on type of sectors, as shown in Table 6 (chi-square is 1.200 and Sig.549). This finding is consistent with previous studies such as Ahmadzadah et al. (2011) finding that found no significant relation between adoption of the activity-based costing technique and industry type within Iranian companies. Added to this is Gosselin's (1997) finding that found similar results within Canadian manufacturing companies. 
Table 6: Chi-Square Tests Implementers Based on Type of Sector

\begin{tabular}{llll}
\hline & Value & df & Asymp. Sig. (2-sided) \\
\hline Pearson Chi-Square & $1.200(\mathrm{a})$ & 2 & .549 \\
Likelihood Ratio & 1.149 & 2 & .563 \\
Linear-by-Linear Association & .598 & 1 & .439 \\
N of Valid Cases & 82 & & \\
\hline
\end{tabular}

a 1 cells $(16.7 \%)$ have expected count less than 5 . The minimum expected count is 4.29 .

The data analysis for hypotheses number two shows no any relationship between company size- number of employees and $\mathrm{ABC}$ implementation. Because the significant value for size variable is .169 and this more than 0.05, so the second hypotheses rejected. Previous studies such as Clarke et al. (1999) and Krumwiede (1998) argued that the companies' size has a main role in the implementation of $\mathrm{ABC}$. The results vary from one study to another; for example Ahmadzadah et al. (2011); Bjornenk (1999); Clarke et al. (1999); Krumwiede (1998) and Pierce and Brown (2004) found no significant relationship between ABC adoption and implementation and company size-number of employees. However studies such as Abu Salama (2008); Baird et al. (2004) and Brown et al. (2004) found a strong significant relation between ABC adoption and implementation and company size. To examine if there are statistical significant differences between both ABC Implementers and Non-ABC Implementers based on number of employees, a chi-square was used. The data analysis indicates no significant difference between ABC Implementers and Non-ABC Implementers based on number of employees (chi-square is 1.76 and Sig.759). The data analysis for hypotheses number three shows no any relationship between diversity-number of products and $\mathrm{ABC}$ implementation. Because the significant value for diversity is .814 and this more than 0.05 , so the third hypotheses rejected. The number of products is used to describe the level of product diversity. Cooper (1988) argued that product diversity leads to a higher possible cost distortion and applies when products consume activity resources in different proportions. Several studies have examined the relationship between the decision to implement $\mathrm{ABC}$ and the products diversity, such as Abu Salama (2008); Bjornenak (1999); Brown et al. (2004) and Clarke et al. (1999). The results demonstrate to be helpful of the influence of ABC implementation. However the current study's finding is consistent with the previous studies' findings such as Ahmadzadah et al. (2011).

To know if there are statistical significant differences between both $A B C$ Implementers and Non-ABC Implementers based on the number of products, a chi-square analysis was employed. The data analysis shows no main difference between $A B C$ Implementers and Non-ABC Implementers based on the number of products, (chi-square is 3.663 and Sig .599). The data analysis for hypothesis number four shows no any relationship between level of overhead cost and $A B C$ implementation. Because the significant value for size variable is .268 and this more than 0.05 , so the fourth hypotheses rejected. Previous studies such as Cooper and Kaplan (1988a) argued that overhead was becoming an increasingly larger part of product cost. This led to the distortions making traditional costing systems unable to determine accurate product costs. So, $\mathrm{ABC}$ was seen as a more accurate cost allocation method of overhead. The results regarding the associations between $A B C$ implementation and level of overhead cost were ambiguous; for example, Abu Salama (2008) and Booth and Giacobbe (1997) found a positive association between ABC implementation and the level of overhead cost. However this finding is consistent with the previous studies' findings such as Brierly (2009). Meanwhile it contrasts with previous studies' findings such as Ahmadzadah et al. (2011). In order to study if there are statistically significant differences between ABC Implementers and Non-ABC Implementers based on level of overhead, a chi-square was used in the current study. The data analysis shows no key difference between ABC Implementers and Non-ABC Implementers based on the level of overhead (chi-square is .382 and Sig .944).

\section{Conclusion}

This paper collected the data from questionnaires to study if there are positive relationship between company characteristics and $\mathrm{ABC}$ implementation. The data analysis shows no any relationship between these factors and $\mathrm{ABC}$ implementation. These finding is consistent with previous studies such as Ahmadzadah et al. (2011) finding that found no significant relation between adoption of the activity-based costing 
technique and industry type, company size-number of employees, and diversity-number of products within Iranian companies. These finding is consistent with previous studies such as Brierly (2009) who found no any relationship between level of overhead and $\mathrm{ABC}$ implementation.

Recommendations and Suggestions for Future Research: Several avenues have been identified for future research. The following recommendations are pertinent: Firstly, the current study covered limited ground as it concentrated solely on Jordanian manufacturing shareholding companies listed on the Amman Stock Exchange; a limitation that would negatively affect the generalisability of results. A broader ground for research is recommended for future studies in order to acquire a more comprehensive view of the Jordanian manufacturing companies' perceptions of ABC. Secondly, Only a few researchers like Baird, et al., (2004); (2007) implied that the national culture dimensions could impact the degree of ABC success. Future research should attempt to determine the influence of culture on ABC successful implementation within the Jordanian companies. Thirdly, a review of existing literature showed that only a few studies carried out an investigation of the impact of $\mathrm{ABC}$ on financial performance. Similarly, future research concerning Jordanian manufacturing companies should attempt to find out the relationship between the use of $\mathrm{ABC}$ costing and the enhancement of financial performance. Fourthly, in Thailand, Chongruksut (2002) found that the economic crisis was a significant variable that motivated the adoption of new management accounting innovations such as ABC, for their survival. Actually the influence of global financial crisis to Jordan's economic was not strong as the influence of Thailand crisis to the Thai economic in 1997. The influence of global finacial crisis led to economic recession, rapidly changed the prices of goods and increased in the intensity of competition, and any impact to the international markets will impact Jordan because Jordan is a member of the World Trade Organization and has a number of economic agreements with the United States. Moreover, the global crisis which resulted from the mortgage problem in the United States markets has also been one of the many reasons that triggered companies to step up operations. Future studies should examine the role of economic crisis as a motivating factor in $\mathrm{ABC}$ implementation.

\section{References}

Abu Mogli, A. (2008). The Impact of the Activity Based Costing System on profit Maximization: An Applied Study on Private Hospitals in Amman Governance. Master's Thesis, Middle East University, Amman, Jordan.

Abu Salama, F. A. (2008). Barriers to adopting activity-based costing systems (ABC): an empirical investigation using cluster analysis. PhD Thesis, Dublin Institute of Technology, Dublin, Ireland.

Abrahamson, E. (1991). Managerial fads and fashions: The diffusion and rejection of innovations. The Academy of Management Review, 16(3), 586-612.

Ahamadzadeh, T., Etemadi, H. \& Pifeh, A. (2011). Exploration of Factors Influencing on Choice the ActivityBased Costing System in Iranian Organizations. International Journal of Business Administration, 2(1), 61.

Al-Khadash, H. \& Feridun, M. (2006). Impact of strategic initiatives in management accounting on corporate financial performance: evidence from Amman Stock Exchange. Managing Global Transitions, 4(4), 299 313.

Al-Omiri, M. \& Drury, C. (2007). A survey of factors influencing the choice of product costing systems in UK organizations. Management Accounting Research, 18(4), 399-424.

Arnaboldi, M. \& Lapsley, I. (2005). Activity-based Costing in Health Care: A UK Case Study. Research in healthcare financial management, 10(1), 61-75.

Askarany, D. \& Smith, M. (2008). Diffusion of innovation and business size: a longitudinal study of PACIA. Managerial Auditing Journal, 23(9), 900-916.

Baird, K., Harrison, G. \& Reeve, R. (2007). Success of Activity Management Practices: the Influence of Organizational and Cultural Factors. Accounting \& Finance, 47(1), 47-67.

Baird, K. M., Harrison, G. L. \& Reeve, R. C. (2004). Adoption of Activity Management practices: a note on the Extent of Adoption and the Influence of Organizational and Cultural factors. Management Accounting Research, 15(4), 383-399.

Bjornenak, T. (1997). Diffusion and accounting: the case of ABC in Norway. Management Accounting Research, 8(1), 3-17. 
Booth, P. \& Giacobbe, F. (1997). Activity-Based Costing in Australia Manufacturing firms: Key Survey Findings. Management Accounting Issues Report. Management Accounting Centre of Excellence of ASCPA, No.5, March 1997, pp.1-6.

Bouma, G. D. \& Ling, R. (2004). The Research Process. Oxford: Oxford University Press,

Brierley, J. A. (2009). An Examination of the Factors Influencing the Level of Consideration for Activity-based Costing. International Journal of Business and Management, 3(8), 58.

Brown, D. A., Booth, P. \& Giacobbe, F. (2004). Technological and organizational influences on the adoption of activity based costing in Australia. Accounting \& Finance, 44(3), 329-356.

Brown, R. (2004). An Empirical Study of Activity-based Costing Systems in Ireland. The Irish Accounting Review, 11(1), 33-55.

Byrne, S., Stower, E. \& Torry, P. (2009). Is ABC adoption a success in Australia? The Journal of Applied Management Accounting Research, 7(1), 37-51.

Campbell, R., Brewer, P. \& Mills, T. (1997). Designing an Information System Using Activity-based Costing and the Theory of Constraints. Journal of Cost Management, 11, 16-25.

Chung, L. H., Schoch, H. P. \& Teoh, H. Y. (1997). Activity-based costing in Singapore: A synthesis of evidence and evaluation. Accounting Research Journal, 10(2), 125-141.

Clarke, P. J., Hill, N. T. \& Stevens, K. (1999). Activity-Based Costing in Ireland: Barriers to, and Opportunities for Change. Critical Perspectives on Accounting, 10(4), 443-468.

Cohen, S., Venieris, G. \& Kaimenaki, E. (2005). ABC: adopters, supporters, deniers and unawares. Managerial Auditing Journal, 20(9), 981-1000.

Cooper, R. (1990).The Rise of Activity-based Costing: Parts 1, 2, 3 \& 4. Journal of Cost Management (19881990).

Cooper, R. (1991). A structured approach to implementing ABC. Accountancy (UK), 78-80.

Cooper, R. \& Kaplan, R. S. (1988). Measure Costs Right: Make the Right Decisions. Harvard Business Review, 66(5), 96-103.

Datar, S. \& Gupta, M. (1994). Aggregation, Specification and Measurement Errors in Product Costing. The Accounting Review, 69(4), 567-591.

Faudziah, K. \& Rababah, L. (2011). Adoption and implementation of activity based costing system in Jordanian manufacturing companies. published at the International Business Information Management Conference (17th IBIMA). Milan, Italy.

Faudziah, K. \& Rababah, L. (2012).Management Accounting Change: ABC Adoption and Implementation. Journal of Accounting and Auditing: Research \& Practice. (2012), USA. Article ID 349927.

Fei, Z. Y. \& Isa, C. R. (2010). Behavioral and Organizational Variables Affecting the Success of ABC Success in China. African Journal of Business Management, 4(11), 2302-2308.

Fei, Z. Y. \& Isa, C. R. (2010). Factors Influencing Activity-Based Costing Success: A Research Framework. International journal of trade, economics and finance, 1(2) 2010-023X.

Chongruksut, W. (2002). The Adoption of Activity-based Costing in Thailand. Unpublished PhD thesis, Victoria: Victoria University.

Greene, A. H. \& Flentov, P. (1991). Managing Performance: Maximizing the Benefit of Activity-based Costing. Emerging Practices in Cost Management, J5-1.

Gunasekaran, A. (1999). A Framework for the Design and Audit of an Activity-based Costing System. Managerial Auditing Journal, 14(3), 118-127.

Gosselin, M. (1997). The Effect of Strategy and Organizational Structure on the Adoption and Implementation of Activity-based Costing. Accounting, Organizations and Society, 22(2), 105-122.

Hair, J. F., Anderson, R. E., Tatham, R. L. \& Black, W. C. (1998). Multivariate data Analysis. New Jersey, Prentice Hall.

Hutaibat, K. A. (2005). Management Accounting Practices in Jordan: A Contingency Approach. Unpublished PhD thesis, Bristol: Bristol University.

Innes, J. \& Mitchell, F. (1990). The Process of Change in Management Accounting: some field study evidence. Management Accounting Research, 1(1), 3-19.

Innes, J. \& Mitchell, F. (1995).A survey of activity-based costing in the UK's largest companies. Management Accounting Research, 6(2), 137-153.

Innes, J., Mitchell, F. \& Sinclair, D. (2000). Activity-based Costing in the UK's largest companies: a comparison of 1994 and 1999 survey results. Management Accounting Research, 11(3), 349-362.

Kaplan, R. (1988). One cost system isn't enough. Harvard Business Review, January- February, 61-66. 
Kaplan, R. \& Anderson, G. (2004). Time-driven activity-based costing. Harvard Business Review, 82, 121-138.

Khaleel, S. (2003). Development of Cost Systems in the Jordanian Corporation through Applying Activitybased Costing: Case study. Unpublished Master's Thesis, Yarmouk University, Irbid, Jordan.

Krishnan, A. (2006). An Application of Activity Based Costing in Higher Learning Institution: A Local Case Study. Contemporary Management Research, 2(2), 75-90.

Krumwiede, K. (1998). The Implementation Stages of Activity-Based Costing and the Impact of Contextual and Organizational Factors. Journal of Management Accounting Research, 10, 239-277

Luther, R. G. \& Longden, S. (2001). Management Accounting in Companies Adapting to Structural Change and Volatility in Transition Economies: a South African study. Management Accounting Research, 12(3), 299-320.

Maelah, R. \& Ibrahim, D. N. (2006). Activity-Based Costing (ABC): Adoption Among Manufacturing Organizations-The Case of Malaysia. International Journal of Business and Society, 7(1), 70-101.

Majid, J. A. \& Sulaiman, M. (2008). Implementation of Activity Based Costing in Malaysia: A case study of two companies. Asian Review of Accounting, 16(1), 39-55.

Malmi, T. (1997). Towards Explaining Activity-based Costing Failure: Accounting and Control in a Decentralized Organization. Management Accounting Research, 8, 459-480.

Malmi, T. (1999). Activity-based costing diffusion across organizations: an exploratory empirical analysis of Finnish firms. Accounting, Organizations and Society, 24, 649-672.

Marie, A. \& Rao, A. (2010). Is Standard Costing Still Relevant? Evidence from Dubai Management Accounting Quarterly, 11(2), 1 - 10.

Popesko, B. (2010). Utilization of Activity-Based Costing system in manufacturing industries-Methodology, Benefits and Limitations. International Review of Business Research Papers, 6(1), 1-17.

Rahmouni, A. F. A. \& Charaf, K. (2010). Success of Activity-Based Costing Projects in French Companies: The Influence of Organizational and Technical Factors. (October 2, 2010). Retrieved from http://ssrn.com/abstract=1686246.

Rasiah, D. (2011). Why Activity Based Costing (ABC) is still Lagging Behind the Traditional Costing in Malaysia? Journal of Applied Finance \& Banking, 1(1), 83-106.

Shields, M. D. (1995). An Empirical Analysis of firms' Implementation Experiences with Activity-based Costing. Journal of Management Accounting Research, 7(1), 148-165.

Stratton, W. O., Desroches, D., Lawson, R. A. \& Hatch, T. (2009). Activity-Based Costing: Is It Still Relevant? Management Accounting Quarterly, 10(3).

Turney, P. B. B. (1996). Activity Based Costing. The Performance Breakthrough. London: CLA.

Turney, P. B. B. \& Stratton, A. J. (1992). Using ABC to Support Continuous Improvement. Management Accounting, 74(3), 46-50.

Van Nguyen, H. \& Brooks, A. (1993). An Empirical Investigation of Adoption Issues Relating to Activity-based Costing. Asian Review of Accounting, 5(1), 1-18.

Velmurugan, M. S. \& Nahar, W. N. A. B. W. (2010).Factors Determining the Success or Failure of ABC Implementation. Cost Management, 24(5), 35.

Vongchavalitkul, B. (2010). Implementing Activity-Based Costing (ABC) in Middle Hospital: A Case Study. Retrieved 2010 from http://www.docstoc. com/docs/ 27393335/Implementing-Activity---BasedCosting-\%28ABC\%29-in-Middle Hospital-A-Case. 